\title{
Faktor Risiko Terjadinya Kejadian Luar Biasa (KLB) Hepatitis A di Kabupaten Tangerang Tahun 2016
}

\section{Risk Factor of Hepatitis A Virus (HAV) Outbreak at Tangerang District in 2016}

\author{
Nenden Hikmah Lailaa,b, Renti Mahkotaa*, Elvieda Sariwatic, Dwi Agus Setiabudid \\ aDepartemen Epidemiologi, Fakultas Kesehatan Masyarakat, Universitas Indonesia, Lantai 1 Gedung A, Kampus Baru UI Depok 16424.

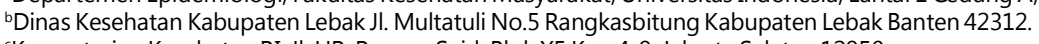 \\ cKementerian Kesehatan RI, Jl. HR. Rasuna Said, Blok X5 Kav. 4-9, Jakarta Selatan 12950. \\ ${ }^{\mathrm{d} D i n a s}$ Kesehatan Kabupaten Tangerang, Komplek Perkantoran Tigaraksa, Jl. Abdul Hamid 2, Kadu Agung, Tigaraksa, Kadu Agung, Tigaraksa, Tangerang, Banten 15720.
}

\section{A B STRAK}

Hepatitis A adalah penyakit hati akibat virus hepatitis A yang dapat menyebabkan kesakitan ringan sampai berat. Di Indonesia Hepatitis A sering muncul dalam Kejadian Luar Biasa (KLB). Tahun 2014 tercatat 3 Provinsi dan 4 Kabupaten terjadi KLB dengan jumlah penderita 282 Penyelidikan epidemiologi ini bertujuan untuk mengetahui gambaran KLB dan mengidentifikasi faktor risiko KLB Hepatitis A di Kabupaten Tangerang tahun 2016. Desain studi yang digunakan dalam penelitian ini adalah desain kasus kontrol. Penyelidikan dilaksanakan pada bulan Maret 2016 di Kabupaten Tengerang. Besar sampel yaitu 44 kasus dan kontrol sebanyak 95. Data yang dikumpulkan dalam penyelidikan ini berupa data primer dan sekunder. Data primer meliputi identifikasi responden dan faktor risiko Hepatitis A. Penyelidikan dilakukan dengan metode wawancara menggunakan kuesioner terstruktur serta observas lingkungan. Data sekunder diambil berdasarkan laporan puskesmas, catatan dinas kesehatan Kabupaten Tangerang dan data demografi. Data dianalisis dengan Stata menggunakan uji bivariate: Chi Square $\left(X^{2}\right)$ dan multivariate; regresi logistik. KLB terjadi pada bulan Februari-Maret 2016 dengan kasus sebanyak 44, kasus terbanyak terjadi pada minggu ke-10 pada bulan Maret 2016. KLB hepatitis A berdasarkan kelompok umur 6 10 tahun sebesar 3 orang (6.82\%) lebih sedikit dibanding umur 11-16 tahun yaitu 41 orang (93.18\%), KLB hepatitis A berdasarkan jenis kelamin lebih banyak pada perempuan yaitu 24 orang (54.55\%) dibanding lakilaki yaitu 20 orang (45.45\%) dengan OR 0.71 (CI95\% 0.32-1.56). Faktor risiko diantaranya tidak cuci tangan pakai sabun sehabis BAB OR 7.90 (CI 95\% 3.14 -19.88) dan jenis kantin yang digunakan (Warung 2) OR 2.92 (CI 95\% 1.21 - 7.02). KLB hepatitis A terjadi karena berbagai faktor risiko diantaranya tidak cuci tangan pakai sabun sehabis bab dan jenis kantin yang digunakan (Warung 2). Selain itu PHBS penjamah makanan kurang baik dan sanitasi lingkungan juga buruk. Upaya pencegahan bisa dilakukan melalui perbaikan sanitasi sekolah dan penyuluhan tentang PHBS dan imunisasi hepatitis A

Kata kunci: hepatitis A, penyelidikan epidemiologi, higiene personal, imunisasi

\section{Pendahuluan}

Hepatitis A adalah penyakit hati akibat virus hepatitis A yang dapat menyebabkan kesakitan ringan sampai berat. Diperkirakan HAV penyebab 1,5 juta kasus secara global per tahun. Dampak ekonomi dari wabah tersebut seperti epidemi Shanghai pada tahun 1988 yang menyerang sekitar 300.000 orang. ${ }^{1}$ Di negaranegara berkembang dengan kondisi sanitasi yang buruk dan praktek-praktek higienis, kebanyakan anakanak (90\%) telah terinfeksi hepatitis A virus sebelum usia 10 tahun. $^{2}$
A B S TRACT

Hepatitis $A$ is a viral infectious disease that cause mild to severe liver diseases. The Epidemics related to contamination of food or water will erupt explosively. In developing countries with poor sanitary conditions and hygienic practices, most children (90\%) have been infected. In Indonesia total outbreaks of hepatitis $\mathrm{A}$ in three provinces and four districts / cities in 2014 is about 282 cases. This outbreak investigation conducted to describe the outbreak and explain the factors outbreaks of hepatitis A in Tangerang district in 2016. This is a case-control study. Investigations conducted on March, 2016 in Tangerang district. The sample size was 44 and control 95. The data collected from primary and secondary. Primary data includes identification of respondents and risk factors Hepatitis A. Investigations conducted by interview using a structured questionnaire and environmental observation. Secondary data is taken based on report of community Health centers, Tangerang district health office records and laboratory result by BBTKLPP Jakarta. Data was analyzed using Stata with bivariate; chi square (X2) and multivariate; logistic regression. The outbreak start from February-March 2016 with total cases 44 , the highest cases occurred on 10th week. Outbreaks of hepatitis A by age group 6-10 years old was 3 people (6.82\%) less than > 11-16 years old was 41 people (93.18\%) with OR 1.78 (CI95\% 0.43-10.48). By sex more women were 24 people (54.55\%) than men were 20 (45.45\%) with OR was 0,71 (CI95\% 0.32-1.56). The risk factors include washing hands with no soap after using toilet OR 7.90 (CI 95\% 3.14 -19.88) and types of canteen used OR 2.92 (CI 95\% 1.21 - 7.02). Outbreaks of hepatitis A occur due to various risk factors including hand washing with no soap and types of canteen used. Hygiene personal of food handler was horrible and environmental sanitation was also bad. Prevention efforts can be done through improvement of school sanitation and education about hygiene personal and immunization of hepatitis A.

Keywords: hepatitis A, outbreak investigation, hygiene personal, imunization

Dinegara maju wabah sering berjalan dengan sangat lambat, wabah dengan pola "Common source" dapat meluas dengan cepat. KLB karena pola penularan "Common source" berkaitan dengan makanan yang terkontaminasi oleh penjamah makanan dan produk makanan yang terkontaminasi. ${ }^{3}$ Pada daerah dengan sanitasi lingkungan yang rendah, infeksi terhadap virus ini umumnya menyerang anakanak sekolah hingga dewasa muda dengan jalur *Korespondensi: Nenden Hikmah Laila, FETP 2015, Departemen Epidemiologi, Gedung A Lt. I, Fakultas Kesehatan Masyarakat, Universitas Indonesia, Depok 16424, Indonesia; : Email. meilaila_tofu@yahoo.com; HP: +6285218504400 
penularan melalui fecal-oral. ${ }^{4}$ Timbulnya penyakit ini berhubungan erat dengan sanitasi yang buruk dan rendahnya kebiasaan higiene personal, seperti cuci tangan. Seperti umumnya penyakit akibat virus, penderita hepatitis A sebagian besar mengalami penyembuhan sendiri (self limiting diseases), dengan kematian sangat kecil 0.1-0.3\%. ${ }^{5}$

Di Indonesia Hepatitis A sering muncul dalam Kejadian Luar Biasa (KLB). Tahun 2010 tercatat 6 KLB dengan jumlah penderita 279, sedangkan tahun 2011 tercatat 9 KLB, jumlah penderita 550. Tahun 2012 sampai bulan juni telah terjadi 4 KLB dengan jumlah penderita $204 .^{4}$

Telah terjadi KLB Hepatitis A berdasarkan penyataan Kepala Dinas Kabupaten Tangerang di salah satu SMP Kabupaten Tangerang pada 18 Maret 2016. Penelitian ini bertujuan untuk mengetahui faktor risiko yang berhubungan dengan Hepatitis A pada KLB Hepatitis A di Kabupaten Tangerang 2016. Dilakukan investigasi terhadap KLB tersebut dengan tujuan menggambarkan kasus hepatitis A yang terjadi dan identifikasi faktor risiko terjadinya KLB tersebut.

\section{Metode Penelitian}

Desain penelitian ini adalah unmatched case control. Penyelidikan KLB Hepatitis A dilakukan di salah satu SD dan SMP Kabupaten Tangerang pada bulan Maret 2016. Kasus adalah semua orang yang mempunyai gejala demam, sakit kepala, lelah, batuk, pilek, mual, muntah, diare, icterus (kekuningan) yang terlihat pada kulit dan mata, air kencing berwarna pekat seperti teh, nafsu makan menurun. Kriteria inklusi kasus adalah siswa usia hingga 16 tahun. Kontrol adalah teman sebangku atau teman main kasus yang tidak mempunyai gejala demam, sakit kepala, lelah, batuk, pilek, mual, muntah, diare, icterus (kekuningan) yang terlihat pada kulit dan mata, air kencing berwarna pekat seperti teh, nafsu makan menurun.

Variabel yang dikumpulkan adalah: (1) karakteristik responden (umur dan jenis kelamin), (2) faktor risiko acara makan bersama, cuci tangan sebelum makan, memakai alat makan basah, cuci alat makan pakai sabun, cuci tangan pakai sabun setelah BAB, makan makanan mentah, tukar-menukar alat makan, makan bersama di satu alas makan, dan jenis kantin yang digunakan (Warung 1, 2, 3, 4, 5, 6, dan 7). Dengan perhitungan besar sampel menggunakan rumus Lemeshow :

$$
\begin{aligned}
& n=\frac{\left[Z_{1}-\alpha / 2 \sqrt{2} P_{2}\left(1-P_{2}\right)+Z_{1}-\beta \sqrt{ } P_{1}\left(1-P_{1}\right)+P_{2}\left(1-P_{2}\right)\right]^{2}}{\left(P_{1}-P_{2}\right)^{2}} \\
& P 1=\frac{(O R) P_{2}}{(O R) P_{2}+\left(1-P_{2}\right)}
\end{aligned}
$$

\section{Keterangan :}

$\mathrm{n} \quad=$ besar sampel

$\mathrm{P}_{1} \quad=$ proporsi responden yang tidak cuci tangan terkena Hepatitis A, yaitu 1,097

$\mathrm{P}_{2} \quad=$ proporsi responden yang cuci tangan terkena Hepatitis A, yaitu 2,167
$Z_{1}-\alpha / 2=$ nilai $Z$ pada derajat kemaknaan (5\%) dan uji hipotesis 2 sisi, nilai $Z=1,960$

$Z_{1}-\beta=$ nilai $Z$ pada kekuatan uji tertentu (80\%), nilai $Z=0,84$

P1 $=5,96 \times 2,16 /(5,96 \times 2,16+(1-2,16)$

$$
=1,09
$$

$n=\left[1,960, \underline{\sqrt{2} \times 2,16(1-2,16)+0,84} \sqrt{1,09(1-1.09)+2,16(1-2,16)]^{2}}\right.$

$n=26,36$

$(1,09-2,16)^{2}$

Dengan demikian perhitungan sampel kasus untuk penelitian ini adalah 26 orang, sedangkan kontrol merupakan perbandingan kasus 1:2.

Setelah dilakukan penyelidikan epidemiologi, kasus dalam KLB Hepatitis A ini diperoleh dari laporan W2 Puskesmas sebanyak 41 orang dengan diagnosis kasus berdasarkan demam, icterus (kekuningan) yang terlihat pada kulit dan mata, air kencing berwarna pekat seperti teh dan surveilans aktif di sekolah sebanyak 3 orang. Kontrol adalah teman main atau teman sebangku kasus yang tidak mempunyai gejala tersebut selama 1 bulan sebelum masa inkubasi sebanyak 95 orang. Pengambilan serum dilakukan pada anak sekolah dan penjamah makanan sebanyak 26 orang.

Penelitian ini rentan terhadap bias seleksi karena informasi tentang paparan dapat mempengaruhi seleksi subyek secara berbeda untuk kelompok kasus dan kelompok kontrol, informasi tentang paparan rentan terhadap kesalahan pengukuran karena data dikumpulkan secara retrospektif melalui ingatan (recal) karena diukur setelah penyakitnya terjadi. Kesalahan pengukuran ini juga dapat menjurus kepada bias informasi. ${ }^{8}$

Analisis data dilakukan dengan analisis bivariat dan multivariat. Analisis bivariat bertujuan untuk menyeleksi variabel yang akan masuk ke analisis multivariat yang diduga sebagai karakteristik responden dan faktor risiko kejadian hepatitis A dengan menggunakan uji chi-square $\left(X^{2}\right)$, yang selanjutnya akan dilakukan analisis multivariat untuk mengetahui besar pengaruh beberapa faktor secara simultan terhadap Hepatitis A dengan uji regresi logistik dengan menggunakan software Stata versi 12. Variabel yang dipilih menjadi kandidat dalam analisis multivariat adalah variabel yang mempunyai nilai $p<0,25$ dalam analisis bivariat.

\section{Hasil}

KLB ini terjadi di sekolah, kejadian pada anak SD sebesar 13,95\% dan SMP lebih besar dibandingkan SD yaitu 83,72\%. KLB Hepatitis A di Kabupaten Tangerang ini terjadi pada minggu ke 8 (Februari 2016) sampai dengan minggu ke 12 (Maret 2016). Dari 44 kasus hanya 39 kasus yang bisa dianalisis (missing 5 kasus). Pada kurva epidemic, kasus-kasus berdasarkan waktu berhasil diwawancara pada minggu ke 13 dengan kontrol 95 orang. Terlihat lonjakan kasus pada minggu ke 10, dan kecenderungan KLB masih berlanjut pada minggu ke 13 (grafik 1). 
Laila, Mahkota, Sariwati, Setiabudi Faktor Risiko terjadinya KLB Hepatitis A di Kab. Tangerang 2016

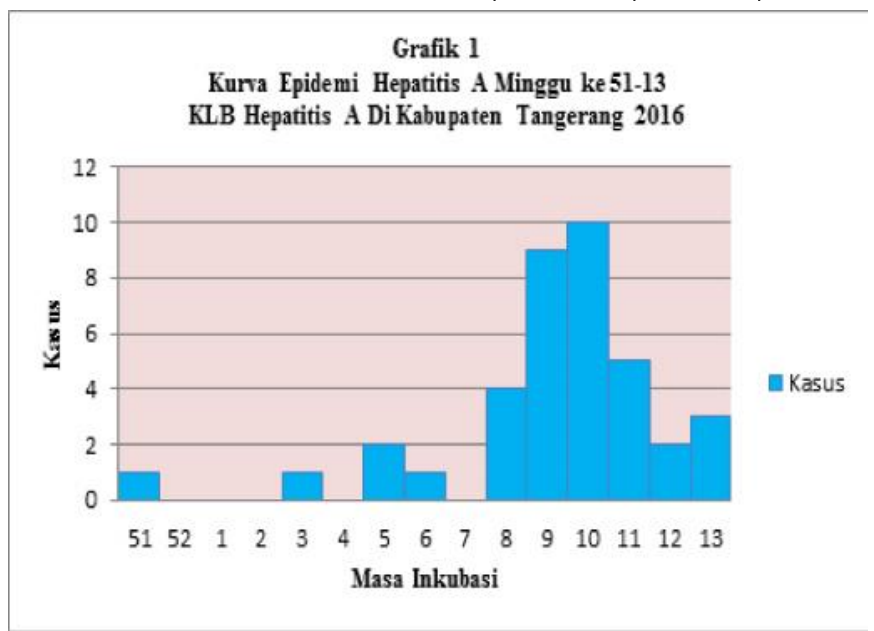

Distribusi Hepatitis A berdasarkan gejala klinis: demam 79,54\%, sakit kepala 90,90\%, lelah 88,64\%, batuk 20,45\%, pilek 31,81\%, mual 90,90\%, muntah $68,18 \%$, diare $36,36 \%$, icterus (kekuningan) yang terlihat pada kulit dan mata $86,36 \%$, air kencing berwarna pekat seperti the $84,09 \%$, nafsu makan menurun $95,45 \%$. Sehingga persentase gejala klinis terbanyak adalah nafsu makan menurun, sakit kepala, mual, lelah, icterus dan urin seperti teh.

TPM di SD berjumlah 4 kantin dan TPM di SMP berjumlah 8 kantin. Sedangkan setelah melalui proses cleaning hanya 7 warung berikut yang bisa dianalisis. Distribusi Hepatitis A berdasarkan TPM yaitu kantin 1 sebanyak 63,63\%, kantin 2 sebanyak 77,27\%, kantin 3 sebanyak 18,18\%, kantin 4 sebanyak 4,55\%, kantin 5 sebanyak 52,27\%, kantin 6 sebanyak 63,63\% dan kantin 7 sebanyak $6,82 \%$. TPM yang paling banyak dikunjungi oleh kasus selama masa penularan adalah kantin 2. Yang selanjutnya kantin 1 dan 6 sebanyak 63,63\%. Sedangkan hasil Pemeriksaan serum dengan RDT IgM/ IgG positif adalah siswa SD sebanyak 2 orang, SMP 4 orang dan penjamah makanan 2 orang.

Untuk faktor risiko dilakukan pendekatan kasus kontrol dengan variabel karakteristik individu dan faktor perilaku (table 1).

Tabel 1. OR Crude Faktor Risiko Hepatitis A di Kaupaten Tangerang 2016

\begin{tabular}{|c|c|c|c|c|c|c|c|c|}
\hline & \multirow{2}{*}{ Variabel } & \multicolumn{2}{|c|}{ Kasus } & \multicolumn{2}{|c|}{ Kontrol } & \multirow{2}{*}{ OR } & \multirow{2}{*}{ C I $95 \%$} & \multirow{2}{*}{$\begin{array}{c}P \\
\text { value }\end{array}$} \\
\hline & & $n$ & $\%$ & $n$ & $\%$ & & & \\
\hline & \multicolumn{8}{|l|}{ Karakteristik individu } \\
\hline \multirow[t]{3}{*}{1.} & $\mathrm{U} \mathrm{m} u \mathrm{r}$ & & & & & & & \\
\hline & $6-10$ & 3 & 6.82 & 11 & 11.58 & 1.78 & $0.47-6.76$ & 0.391 \\
\hline & $11-16$ & 41 & 93.18 & 84 & 88.42 & & & \\
\hline \multirow[t]{4}{*}{2.} & Jenis Kelam in & & & & & & & \\
\hline & Laki-laki & 20 & 45.45 & 51 & 53.68 & 0.71 & $0.32-1.56$ & 0.366 \\
\hline & Perempuan & 24 & 54.55 & 44 & 46.32 & & & \\
\hline & Faktor perilaku & & & & & & & \\
\hline \multirow[t]{3}{*}{3.} & Riwayat Makan Bersama & & & & & & & \\
\hline & $\mathrm{Ya}$ & 15 & 34.09 & 19 & 20.00 & 2.068 & $0.85-4.94$ & 0.072 \\
\hline & Tid ak & 29 & 65.91 & 76 & 80.00 & & & \\
\hline \multirow[t]{3}{*}{4.} & Cucitangan sebelum makan & & & & & & & \\
\hline & $\mathrm{Ya}$ & 25 & 56.82 & 70 & 74.47 & 2.216 & $0.96-5.03$ & 0.037 \\
\hline & Tidak & 19 & 43.18 & 24 & 25.53 & & & \\
\hline \multirow[t]{3}{*}{5.} & Memakai alat makan basah & & & & & & & \\
\hline & Ya & 16 & 36.36 & 28 & 29.47 & 1.367 & $0.59-3.09$ & 0.416 \\
\hline & Tidak & 28 & 63.64 & 67 & 70.53 & & & \\
\hline \multirow[t]{3}{*}{6.} & Mencucialat makan pakai & & & & & & & \\
\hline & sabun & 14 & 31.82 & 64 & 67.37 & 4.423 & $1.93-$ & 0.000 \\
\hline & $\begin{array}{l}\text { Ya } \\
\text { Tidak }\end{array}$ & 30 & 68.18 & 31 & 32.63 & & 10.29 * & \\
\hline \multirow[t]{3}{*}{7.} & $\begin{array}{l}\text { Cucitangan pakaisabun } \\
\text { sehabis BAB }\end{array}$ & & & & & & & \\
\hline & $\mathrm{Ya}$ & 7 & 15.91 & 58 & 61.05 & 8.285 & $3.16-$ & 0.000 \\
\hline & Tid ak & 37 & 84.09 & 37 & 38.95 & & $24.01 *$ & \\
\hline \multirow[t]{3}{*}{8.} & Konsumsimakanan mentah & & & & & & & \\
\hline & $\mathrm{Ya}$ & 14 & 31.82 & 19 & 20.00 & 1.866 & $0.75-4.50$ & 0.127 \\
\hline & Tid ak & 30 & 68.18 & 76 & 80.00 & & & \\
\hline \multirow[t]{3}{*}{9 . } & $\begin{array}{l}\text { Kebiasaan tukaran alat } \\
\text { makan }\end{array}$ & 11 & 25.00 & 23 & 24.21 & 1.043 & $0.40-2.54$ & 0.919 \\
\hline & $\mathrm{Ya}$ & 33 & 75.00 & 72 & 75.79 & & & \\
\hline & Tidak & & & & & & & \\
\hline \multicolumn{9}{|c|}{$\begin{array}{l}\text { 10. Kebiasaan makan bersama } \\
\text { dalam satu tempat makan }\end{array}$} \\
\hline & $\mathrm{Ya}$ & 17 & 38.64 & 30 & 31.58 & 1.364 & $0.60-3.05$ & 0.413 \\
\hline & Tidak & 27 & 61.36 & 65 & 68.42 & & & \\
\hline
\end{tabular}


Tabel 1. OR Crude Faktor Risiko Hepatitis A di Kaupaten Tangerang 2016 (Lanjutan)

\begin{tabular}{|c|c|c|c|c|c|c|c|c|}
\hline & \multirow{2}{*}{ Variabel } & \multicolumn{2}{|c|}{ Kasus } & \multicolumn{2}{|c|}{ Kontrol } & \multirow{2}{*}{ OR } & \multirow{2}{*}{ CI 95\% } & \multirow{2}{*}{$P$ value } \\
\hline & & $\mathrm{n}$ & $\%$ & $n$ & $\%$ & & & \\
\hline & \multicolumn{8}{|l|}{ Faktor perilaku } \\
\hline 1. & \multicolumn{8}{|l|}{$\begin{array}{l}\text { Jenis Kantin yang digunakan } \\
\text { a. Warung } 1\end{array}$} \\
\hline & $\mathrm{Ya}$ & 28 & 63.64 & 57 & 60.00 & 1.16 & $0.52-2.63$ & 0.682 \\
\hline & Tidak & 16 & 36.36 & 38 & 40.00 & & & \\
\hline & \multicolumn{8}{|l|}{ b. Warung 2} \\
\hline & $\mathrm{Ya}$ & 34 & 77.27 & 49 & 51.58 & 3.19 & $1.34-8.03$ & $0.004^{*}$ \\
\hline & Tidak & 10 & 22.73 & 46 & 48.42 & & & \\
\hline & \multicolumn{8}{|l|}{ c. Warung 3} \\
\hline & Ya & 8 & 18.18 & 15 & 15.79 & 1.18 & $0.39-3.30$ & 0.724 \\
\hline & Tidak & 36 & 81.82 & 80 & 84.21 & & & \\
\hline & \multicolumn{8}{|l|}{ d. Warung 4} \\
\hline & $\mathrm{Ya}$ & 2 & 4.55 & 6 & 6.32 & 0.70 & $0.06-4.17$ & 0.676 \\
\hline & Tidak & 42 & 95.45 & 89 & 93.68 & & & \\
\hline & \multicolumn{8}{|l|}{ e. Warung 5} \\
\hline & $\mathrm{Ya}$ & 23 & 52.27 & 42 & 44.21 & 1.38 & $0.63-3.01$ & 0.375 \\
\hline & Tidak & 21 & 47.73 & 53 & 55.79 & & & \\
\hline & \multicolumn{8}{|l|}{ f. $\quad$ Warung 6} \\
\hline & Ya & 28 & 63.64 & 54 & 56.84 & 1.32 & $0.60-2.99$ & 0.448 \\
\hline & Tidak & 16 & 36.36 & 41 & 43.16 & & & \\
\hline & \multicolumn{8}{|l|}{ g. Warung 7} \\
\hline & Ya & 3 & 6.82 & 11 & 11.58 & 0.55 & $0.09-2.28$ & 0.385 \\
\hline & Tidak & 41 & 93.18 & 84 & 88.42 & & & \\
\hline
\end{tabular}

Tabel 2. Model Awal Faktor Risiko Hepatitis A di Kabupaten Tangerang 2016

\begin{tabular}{lccc}
\hline \multicolumn{1}{c}{ Variabel } & OR & CI & P value \\
\hline Riwayat makan bersama & 1.62 & $0.63-4.16$ & 0.311 \\
Tidak cuci tangan sebelum makan & 1.33 & $0.53-3.34$ & 0.540 \\
Tidak mencuci alat makan pakai sabun & 1.54 & $0.54-4.34$ & 0.410 \\
Tidak cuci tangan pakai sabun sehabis BAB & 5.42 & $1.63-18.03$ & 0.006 \\
Konsumsi makanan mentah & 1.09 & $0.41-2.90$ & 0.860 \\
Jenis kantin yang digunakan (Warung 2) & 2.92 & $1.17-7.30$ & 0.021 \\
\hline
\end{tabular}

Tabel 3. Full Model Hepatitis A di Kabupaten Tangerang 2016

\begin{tabular}{lccc}
\hline \multicolumn{1}{c}{ Variabel } & OR & CI & P value \\
\hline Tidak cuci tangan pakai sabun sehabis BAB & 7.90 & $3.14-19.88$ & $<0.001$ \\
Jenis kantin yang digunakan (Warung 2) & 2.92 & $1.21-7.02$ & 0.017 \\
\hline
\end{tabular}

Dari 11 variabel hasil analisa faktor risiko, terlihat bahwa yang dipilih menjadi kandidat multivariate adalah faktor risiko yang nilai $P$ value nya $<0,25$ yaitu riwayat makan bersama dengan $P$ value 0.07 , tidak cuci tangan sebelum makan $P$ value 0.03 , tidak mencuci alat makan pakai sabun $P$ values 0.00 , tidak cuci tangan pakai sabun sehabis bab $P$ value 0.00 , konsumsi makanan mentah $P$ value 0.12 , dan jenis kantin yang digunakan (Warung 2) (table 1).

Hanya variabel tidak cuci tangan pakai sabun sehabis BAB yang mempunyai hubungan signifikan dengan OR 7,90 (CI 95\% 3.14-19.88), yang berarti orang yang tidak cuci tangan pakai sabun sehabis BAB mempunyai risiko kejadian Hepatitis A sebesar 7,9 kali dibanding orang yang cuci tangan pakai sabun sehabis $\mathrm{BAB}$ dan jenis kantin yang digunakan (Warung 2) dengan OR 2,92 (CI 95\% 1.21-7.02) yang berarti jenis kantin yang digunakan (Warung 2) mempunyai risiko kejadian Hepatitis A sebesar 2,92 kali dibanding kantin lain. Dengan demikian model akhir pada penelitian ini adalah tidak cuci tangan pakai sabun sehabis BAB dan jenis kantin yang digunakan (Warung 2) (table 3).

\section{Diskusi}

Penyakit Hepatitis merupakan masalah kesehatan masyarakat di dunia termasuk di Indonesia. Hepatitis A dan E, sering muncul sebagai kejadian Luar Biasa, ditularkan secara fecal-oral dan biasanya berhubungan dengan Perilaku Hidup Bersih dan Sehat (PHBS), bersifat akut dan dapat sembuh dengan baik. Melihat kenyataan bahwa Hepatitis merupakan masalah kesehatan masyarakat yang serius dan mengglobal, maka pada tahun 2010 pada sidang WHA (World Health Assembly) ke 63 di Geneva tanggal 20 Mei 2010, Indonesia bersama Brazil dan Colombia menjadi sponsor utama untuk keluarnya Resolusi tentang Hepatitis Virus, sebagai Global Public Health Concern. Yang menyatakan bahwa: Hepatitis virus merupakan 
salah satu agenda prioritas dunia dan tanggal 28 Juli ditetapkan sebagai Hari Hepatitis Sedunia. ${ }^{9}$

Kejadian KLB di Kabupaten Tangerang lebih besar pada siswa SMP dibandingkan SD yaitu sebesar 83,72\%. Dilihat dari lokasi sekolah, SD dan SMP ini berada di kawasan yang sama. Penyakit ini sangat umum menyerang anak-anak sekolah dan dewasa muda. Sebagaimana daerah di negara berkembang, orang dewasa biasanya sudah kebal dan wabah Hepatitis A (HA) jarang terjadi. Namun adanya perbaikan sanitasi lingkungan di sebagian besar negara di dunia ternyata membuat penduduk golongan dewasa muda menjadi lebih rentan sehingga frekuensi terjadi KLB cenderung meningkat. Didaerah dengan sanitasi lingkungan yang rendah, infeksi umumnya terjadi pada usia sangat muda. ${ }^{3}$ Masa inkubasi adalah 15 sampai dengan 50 hari, rata-rata 28-30 hari. Awal KLB Hepatitis A di Kabupaten Tangerang ini terjadi pada minggu ke 8 sampai dengan minggu ke 12 . terjadi lonjakan kasus pada minggu ke 10, dan kecenderungan KLB masih berlanjut pada minggu ke 13 dan biasanya wabah dengan pola common source dapat meluas dengan cepat.

Di sebagian besar negara berkembang, infeksi virus hepatitis A terjadi pada masa kanak-kanak umumnya asimtomatis atau dengan gejala sakit ringan. Infeksi yang terjadi pada usia selanjutnya hanya dapat diketahui dengan pemeriksaan laboratorium terhadap fungsi hati. Distribusi Hepatitis A berdasarkan gejala klinis pada KLB di Kabupaten Tangerang ini mempunyai proporsi: demam 79,54\%, sakit kepala 90,90\%, lelah $88,64 \%$, batuk 20,45\%, pilek 31,81\%, mual 90,90\%, muntah $68,18 \%$, diare $36,36 \%$, icterus (kekuningan) yang terlihat pada kulit dan mata $86,36 \%$, air kencing berwarna pekat seperti teh $84,09 \%$, nafsu makan menurun $95,45 \%$. sehingga persentase gejala klinis terbanyak adalah nafsu makan menurun, sakit kepala, mual, lelah, ikterus dan urin seperti teh. Dari berbagai penelitian tentang cara-cara penularan pada manusia dan dari berbagai bukti epidemiologis menunjukkan bahwa infektivitas maksimum terjadi pada hari-hari terakhir dari separuh masa inkubasi dan terus berlanjut sampai beberapa hari setelah timbulnya ikterus (atau pada puncak aktivitas aminotransferase pada kasus anicteric). Pada sebagian besar kasus kemungkinan tidak menular pada minggu pertama setelah ikterus, meskipun ekskresi virus berlangsung lebih lama (sampai 6 bulan) telah dilaporkan terjadi pada bayi dan anak-anak. Ekskresi kronis HAV dalam tinja tidak pernah dilaporkan terjadi.

Sumber KLB dengan pola "common source"umumnya dikaitkan dengan air yang tercemar, makanan yang tercemar oleh penjamah makanan, termasuk makanan yang tidak dimasak atau makanan matang yang tidak dikelola dengan baik sebelum dihidangkan. TPM yang paling banyak dikunjungi oleh kasus selama masa penularan adalah kantin 2 sebanyak 77,27\%. Yang selanjutnya kantin 1 dan 6 sebanyak 63,63\%. Sedangkan hasil Pemeriksaan serum dengan RDT IgM/IgG positif adalah siswa SD sebanyak 2 orang, SMP 4 orang dan penjamah makanan 2 orang.
Penyebaran secara fecal-oral sehingga pencegahan masih sulit karena adanya karier dari virus tipe A yang sulit diterapkan. Virus ini resisten terhadap cara-cara sterilisasi biasa, termasuk klorinasi. Sanitasi yang baik, kesehatan umum, dan pembuangan tinja yang baik sangat penting. Tinja, darah dan urin kasus harus dianggap infeksius. Virus dikeluarkan di tinja mulai sekitar 2 minggu sebelum ikterus. ${ }^{10}$

Berdasarkan tabel 2 terlihat bahwa faktor risiko tidak cuci tangan sebelum makan tidak mempunyai hubungan signifikan dengan kejadian Hepatitis A dengan $O R$ 1,33. Walaupun demikian menurut Firdous praktek cuci tangan mempunyai hubungan signifikan dengan kejadian Hepatitis A dengan OR 3,0.11 Hal ini sesuai dengan penyelidikan epidemiologi KLB Hepatitis A di pedesaan China yang menyatakan bahwa kebiasaan cuci tangan merupakan faktor risiko terjadinya Hepatitis A walaupun bukan merupakan faktor utama. ${ }^{12}$ Timbulnya penyakit ini berhubungan erat dengan sanitasi yang buruk dan rendahnya kebiasaan higiene personal, seperti cuci tangan. Pencemaran dapat terjadi karena higiene penjamah makanan yang buruk, serta makanan dan minuman yang tidak dimasak dengan baik. Epidemi yang terjadi akibat kontaminasi pada air dan makanan dapat mengakibatkan ledakan kasus, dan menimbulkan kerugian ekonomi yang tidak sedikit.

Faktor risiko tidak mencuci alat makan pakai sabun tidak mempunyai hubungan signifikan dengan kejadian Hepatitis A dengan OR 1,54 begitu juga dengan konsumsi makanan mentah dengan OR 1,09. Menurut Sumarni cuci alat makan pakai sabun tidak mempunyai hubungan signifikan dengan kejadian Hepatitis A dengan OR 0,46. Akan tetapi kebiasaan makan makanan yang matang mempunyai hubungan signifikan dengan kejadian Hepatitis A sebesar 3,11 kali. ${ }^{13}$

Model akhir pada penelitian ini menunjukkan faktor risiko tidak cuci tangan pakai sabun sehabis BAB mempunyai hubungan signifikan dengan kejadian Hepatitis A OR 7.90 (CI 95\% 3.14 -19.88), yang berarti orang yang tidak cuci tangan pakai sabun sehabis $B A B$ mempunyai risiko kejadian Hepatitis A sebesar 7,90 kali dibanding orang yang cuci tangan pakai sabun sehabis BAB. Hal ini sesuai dengan Afudin yang mengatakan responden yang hanya kadang-kadang (tidak selalu) mencuci tangan dengan air+sabun sesudah BAB (tidak higienis) berpotensi terkena infeksi HAV 4,6 kali dibandingkan responden yang mempunyai kebiasaan selalu mencuci tangan dengan air+sabun (higienis) sesudah BAB. ${ }^{14}$ Selain itu jenis kantin yang digunakan (Warung 2) dengan OR 2,92 (CI 95\% 1.21 - 7.02) yang berarti jenis kantin yang digunakan (Warung 2) mempunyai risiko kejadian Hepatitis A sebesar 2,92 kali dibanding kantin lain. Berdasarkan penelitian Higiene Dan Sanitasi Makanan Jajanan Di Kantin Sekolah Dasar Di Kecamatan Buke Kabupaten Konawe Selatan Tahun 2016 menunjukkan bahwa $100 \%$ responden yang memiliki sarana penjaja belum memenuhi syarat. Sarana penjaja yang tidak memenuhi syarat yaitu sarana penjaja mudah 
dibersihkan, tersedia tempat untuk: air bersih, tempat penyimpanan bahan makanan, penyimpanan makanan jadi/siap disajikan, penyimpanan peralatan, tempat cuci (tangan, alat dan bahan makanan) serta makanan yang dijajakan terlindungi dari debu dan pencemaran. ${ }^{15}$

Secara umum pada penelitian Sasoka faktor risiko higiene personal terhadap kejadian Hepatitis A menunjukkan nilai OR 5.71, yang berarti bahwa seseorang dengan higiene personalyang buruk memiliki risiko untuk terkena Hepatitis A sebesar 5,71 lebih besar dibandingkan dengan orang yang memiliki hygiene perseorangan yang baik. ${ }^{16}$ Menurut Notoatmodjo tingkat kesehatan seseorang ditentukan oleh cara seseorang menentukan perilaku dari pengetahuan yang dia dapat. Perilaku seseorang merupakan respons terhadap suatu hal (stimulus) yang memiliki kaitan dengan sakit dan penyakit, sistim kesehatan, makanan dan juga lingkungannnya. Respons yang muncul atas perilaku kesehatan akan menentukan kondisi sehat atau sakitnya orang tersebut. ${ }^{17}$

Cara yang paling penting dalam mencegah infeksi yaitu meningkatkan sanitasi lingkungan untuk menghindari kontaminasi tinja ke dalam makanan dan air. Begitu juga menurut CDC menyatakan bahwa cara terbaik untuk mencegah penularan HAV adalah dengan upaya menghindari agar air dan makanan tidak terkontaminasi HAV, terutama diarahkan pada penyediaan air bersih yang memadai dan melalui penerapan hygiene perorangan..$^{18}$ Selain itu sampai saat ini, imunisasi pasif dengan IG menjadi satu-satunya cara sebagai profilaksis terhadap hepatitis $\mathrm{A}^{19}$ walaupun di Indonesia sendiri belum dimasukan ke dalam program kesehatan karena harga vaksin yang mahal.

\section{Simpulan dan Saran}

Telah terjadi KLB Hepatitis A di salah satu SD, SMP dan SMK di Kabupaten Tangerang dengan jumlah kasus 44 kasus. Berdasarkan kurva epidemiologi, puncak KLB terjadi pada minggu ke-10 dengan jumlah 10 orang. Penularan berasal dari satu sumber (ditemukan 1 kasus yang diduga sebagai sumber penularan). Berdasarkan sekolah, kasus tersebar di SD, SMP dan SMK di Kabupaten Tangerang. Gejala klinis terbanyak adalah nafsu makan menurun sebesar 95,45\%, kemudian sakit kepala 90,90 mual sebesar 90,90\%, lelah sebesar $88,64 \%$, ikterus sebesar 86,36\% dan urin seperti teh sebesar 84,09\%. Model akhir penelitian ini menunjukkan faktor risiko penyebab KLB hepatitis A di Kabupaten Tangerang adalah tidak cuci tangan pakai sabun sehabis BAB dengan OR 7.90 (CI 95\% 3.14 19.88) dan jenis kantin yang digunakan (Warung 2) OR 2.92 (CI 95\% 1.21 - 7.02).

Untuk pengendalian dan pencegahan KLB Hepatitis A disarankan untuk melakukan upaya pencegahan melalui imunisasi Hepatitis A, perilaku dan manipulasi lingkungan.

\section{Ucapan Terima Kasih}

Saya ucapkan terima kasih pada Prof.Dr.dr.Ratna Djuwita, MPH, Dr.dr.Tri Yunis Miko Wahyono, M.Sc dan
dr.Yovsyah, M.Kes yang telah memberikan masukan berharga dalam penulisan manuskrip ini. Widya dkk; BBTKLPP Jakarta dan pihak sekolah di Kabupaten Tangerang untuk kerjasamanya selama investigasi.

Conflict of interest. saya nyatakan bahwa yang bersangkutan diatas tidak mempunyai kepentingan apapun dalam penelitian ini.

\section{Referensi}

1. Zuckerman JN, Jong EC. Travelers' vaccines. 2nd ed. Shelton, CT: People's Medical Pub. House; 2010. xii, 573 p. p.

2. WHO. Hepatitis A 2016 [Available from: http:// www.who.int/mediacentre/factsheets/fs328/en/

3. Chin J. Manual Pemberantasan Penyakit Menular, Edisi 17, Cetakan II. CV Infomedika. 2007.

4. Kemenkes. Pedoman Pengendalian Hepatitis Virus. Jakarta: Ditjen PP \&amp; PL; 2012.

5. Kemenkes. Buku Pedoman Penyelidikan dan Penanggulangan Kejadian Luar Biasa Penyakit Menular dan Keracunan Makanan (Pedoman Epidemiologi Penyakit). Jakarta: Dirjen PP\&PL; 2011.

6. Lemeshow S. Adequacy of sample size in health studies. Chichester: Wiley; 1990.

7. Sakti AP. Hubungan Pengetahuan, Sikap dan Praktik Pencegahan Hepatitis A Dengan Kejadian Hepatitis A Pada Siswa SMAN 4 Depok 2012. Depok2012.

8. Murti B. Prinsip dan metode riset epidemiologi. Yogyakarta: UGM. 1997.

9. Budijanto D. Waspada 2,9 Juta Lebih Penduduk Indonesia Mengidap Hepatitis 2015 [Available from: http:// www.pusdatin.kemkes.go.id/article/view/15073000001/wa-s-p-a-d-a-2-9-juta-lebih-penduduk-indonesiamengidap-hepatitis.html.

10. Mansjoer A. Kapita selekta kedokteran. Jakarta: Media Aesculapius. 2000.

11. Firdous U. Cuci Tangan Sebelum Makan Menurunkan Risiko Kejadian Hepatitis Akut Klinis. Buletin Penelitian Kesehatan. 2005:33(3 Sept).

12. Yu P, Huang L, Li H, Liu M, Zong J, Li C, et al. Epidemiological investigation of an outbreak of hepatitis A in rural China. Int J Infect Dis. 2015;33:191-5.

13. Sumarni I, Susanna D. Kondisi Kesehatan Lingkungan Pesantren dan Perilaku Hidup Bersih dan Sehat Siswa dengan Kejadian Hepatitis. Kesmas: National Public Health Journal. 2014;9(2):179-86.

14. Afudin A. Faktor-faktor yang Berhubungan dengan Kejadian Infeksi Hepatitis A Virus (HAV) di Kabupaten Kebumen Tahun 2001 (Studi Kasus Kontrol KLB Hepatitis). 2003.

15. Ramadani ER, Nirmala F, Mersatika A. Higiene Dan Sanitasi Makanan Jajanan Di Kantin Sekolah Dasar Di Kecamatan Buke Kabupaten Konawe Selatan Tahun 20162016 [cited 2016 April, 15]. Available from: http://ojs.uho.ac.id.

16. Sasoka DS, Satyabakti P. The Relationship Between Personal Hygiene with Hepatitis a Incident in Students. Jurnal Berkala Epidemiologi. 2014;2(3):331-41.

17. Notoatmodjo P-PDIK. Masyarakat. Jakarta: Rineka Cipta. 2003.

18. CDC. Hepatitis A Questions and Answers for the Public 2016 [cited 2016 August 22,]. Available from: https:// www.cdc.gov/hepatitis/hav/afaq.htm\#transmission.

19. Nelson KE, Williams CM, Graham NMH. Infectious disease epidemiology : theory and practice. Gaithersberg, Md.: Aspen; 2001. 